\title{
JÉGVÉDŐ HÁLÓ HATÁSA AZ ALMA GYÜMÖLCS HÚSKEMÉNYSÉGÉRE ÉS VÍZOLDHATÓ SZÁRAZANYAG-TARTALMÁRA
}

\section{THE EFFECT OF HAIL NET ON THE FLESH FIRMNESS AND WATER SOLUBLE DRY MATTER CONTENT OF APPLES}

\author{
Király Ildikó ${ }^{1^{*}}$, Kepecz Dániel ${ }^{1}$

\begin{abstract}
${ }^{1}$ Kertészeti Tanszék, Kertészeti és Vidékfejlesztési Főiskolai Kar, Neumann János Egyetem, Magyarország
\end{abstract} \\ https://doi.org/10.47833/2020.2.AGR.014
}

\section{Kulcsszavak:}

alma

jégvédő háló

Malus x domestica

gyümölcs beltartalom

\section{Keywords:}

apple

hail net

Malus $x$ domestica

fruit inner content

\section{Cikktörténet:}

Beérkezett 2020. február 20.

Átdolgozva 2020. március 13.

Elfogadva 2020. március 20.

\begin{abstract}
Összefoglalás
A jégvédő háló elsődleges szerepe a jég elleni védelem, de számos egyéb pozitív hatása van az ültetvényben. Azáltal, hogy befolyásolja a mikroklímát, hatása van a gyümölcs minőségére is. Vizsgálatainkban három 'Gala' mutáns ('Anaglo', 'Schniga' és 'Brookfield') szerepelt. A minták fekete jéghálós és jégháló nélküli ültetvényekböl származtak. Vizsgáltuk a gyümölcsök húskeménységét és vízoldható szárazanyagtartalmát.

Abstract

The primary role of the ice protection net is to protect against ice but it has many other positive effects on the plantation. By influencing the microclimate, it also affects the fruit quality. Three 'Gala' mutants ('Anaglo', 'Schniga' and 'Brookfield') were included in our study. The samples were originated from plantations with and without hail net. The flesh firmness and water soluble dry matter content of the fruits were examined.
\end{abstract}

\section{Bevezetés}

\subsection{A jégvédő háló fontossága a gyümölcstermesztésben}

Napjainkban a termesztésben a sikerességhez elengedhetetlen az intenzív és korszerü ültetvények létesítése, valamint a régebbi ültetvények korszerüsítése termesztéstechnológia szintjén. Ehhez nagy segítséget és előnyt jelent a jégvédőháló telepítése. Nevéből eredően elsődleges szerepe az ültetvény jégkártól való védelme. Bizonyos termőterületeken sokszor lehet számítani a jégeső megjelenésére. Főként olyan fajokat és fajtákat érinti a jég okozta kár, ahol a nagy gyümölcsméret és a késői érés jellemző. Ugyanakkor a nyári időszak alkalmával is számolhatunk jégeső megjelenésére, amely a korán érő fajokat és fajtákat is károsithatja.

Mindemellett számos pozitív tényezőt tud biztosítani, mint a kedvező mikroklíma, kedvezőbb növényvédelmi tényezők, valamint befolyásolja a gyümölcs tulajdonságot és a gyümölcstermő növény jellemzőit. Tehát elmondható, hogy a jégvédőháló egyaránt befolyásolja a telepített fajták áruértékét ( $\mathrm{pl}$. beltartalmi érték, íz, húsállomány stb.), illetve termesztési értékeit (pl. termőképesség, termésbiztonság stb.). 
Ezen eredmények elérése nagyban függ a megválasztott jégvédelmi technológiától, illetve a kivitelezés pontosságától. Természetesen a jégvédőháló telepítése önmagában nem mentesít az alapvető helyes fajtahasználat és a szorosan hozzákapcsolódó helyes termesztéstechnológia megválasztása alól.

\subsection{A jégháló szerkezeti felépítése}

Szerkezeti szempontból két különálló egységröl beszélhetünk (1. ábra). Az egyik fö egység maga a háló, a másik pedig a vázrendszer vagy támrendszer. A támrendszer alkotóelemei közé tartoznak az oszlopok és a hozzájuk kapcsolódó úgynevezett papucsok, melyek a süllyedést hivatottak meggátolni; az acélhuzal, a huzalvezető kupakok, az ankercsiga - kilengés elleni védelem, statikai erősítés - valamint a plakettek a háló rögzítéséhez a huzalokra. Az oszlopok esetén két féle megoldás közül választhatunk, fa vagy beton kivitelezéssel. A faoszlopok statikai ellenállása nagyobb, tartósságukhoz fontos az impregnálás és általánosságban elmondható, hogy költségvonzata magasabb, mint a betonoszlopos támrendszer létesítése. A betonoszlopok legnagyobb hátránya, hogy a széllökésekkel szemben kevésbé ellenállók, így könnyebben eltörhetnek, mint a faoszlopok és a támrendszer összedölése az ültetvény pusztulását okozhatja. Az ankercsiga megválasztása során egyik legfontosabb tényező a tányér átmérője. A nagyobb tányérátmérő jobb statikai ellenállóságot eredményez. Az ankercsiga acélhuzalok segítségével kapcsolódik a támrendszerhez, a kivitelezés során pedig ügyelni kell, hogy a huzal-támrendszerankercsiga hármas egyenlő szárú háromszög mértani egységet alkossanak [5].

A jégháló rendszer kialakításának típusa lehet lapos vagy oromzatos. Legnagyobb elterjedése az oromzatos kivitelezésnek van. A háló, polietilén anyagból készül, mely UVstabilizátor adalékanyaggal van ellátva. Kettős, illetve hármas fonatú változatokban találkozhatunk vele. A fonatok egy téglalapot alakítanak $\mathrm{ki}$, melynek mérete általánosságban $2,9 \times 7,0 \mathrm{~mm}$. A kisebbik oldal az ültetvény sorra merölegesen, míg a hosszabb oldala az ültetvény sorral párhuzamosan fut. Szakítószilárdsága függ a háló fajtájától, általában ez az érték $2900 \mathrm{~kg} / \mathrm{m}^{2}$. Legnagyobb élettartama (15-20 év) és szakítószilárdsága a fekete hálónak van, ugyanakkor ez a típus a legkisebb fényáteresztő képességgel rendelkezik. A fehér hálók várható élettartama 510 év és ezeknek van a legnagyobb fényáteresztő tulajdonságuk [1]. A kettő közötti átmenetre szolgalának a piros, zöld, valamint a különbözö kombinációk (például: piros-zöld, fekete-fehér, stb.), melyek különböző mértékben engedik át a napfényt [2]. A hálók során alkalmazott plakettek ajánlatos maximális távolsága $1,5 \mathrm{~m}$. Ennek oka pedig a hasadékok elkerülése az illesztések mentén, valamint az egyenletes teherelosztás [5][9].

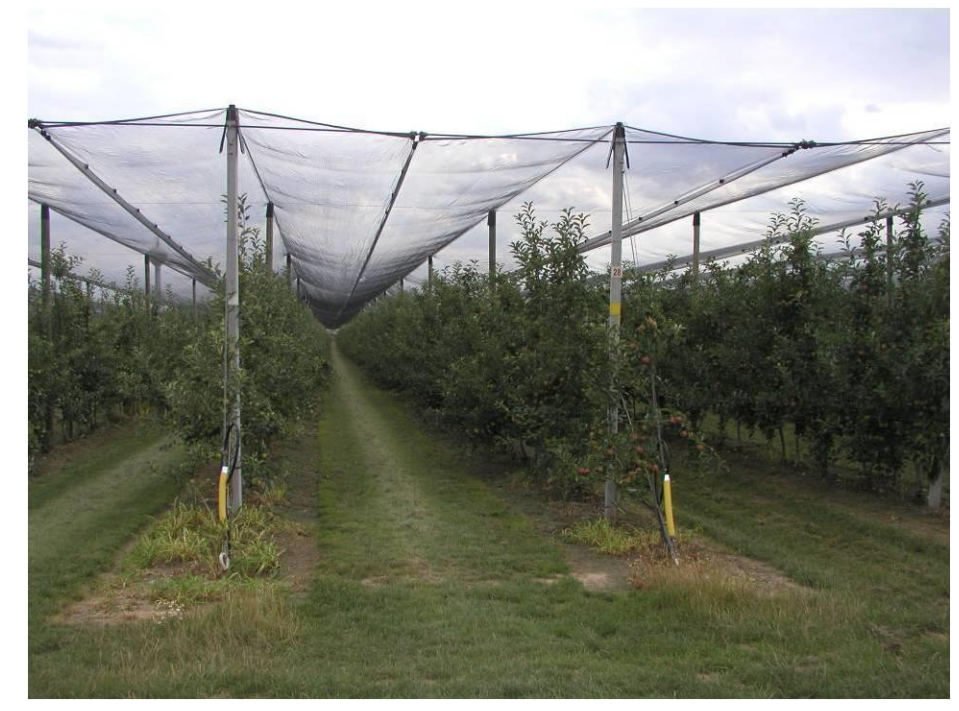

1. ábra. Korszerü, intenzív, jégvédőhálós almaültetvény 


\subsection{A jégháló mikroklíma szabályozó és gyümölcsminőséget befolyásoló hatása}

A jégháló mikroklíma szabályozó és gyümölcsminőséget befolyásoló hatásáról számos tanulmány foglalkozik. A jégvédő háló fényt nyel el, ezért árnyékoló hatással bír. A növények felületi hőmérsékletének csökkentése különösen a napégésre hajlamos gyümölcsfajok, ill. - fajták esetében jelent pozitívumot. A jégvédő háló mérsékli a napi hőingadozást, a légmozgást és az evapotranszspirációt [5][10].

Növényvédelem szempontjából is elönyös lehet a jégvédő háló alatti termesztés, mint azt almamoly esetében tapasztalták [13].

A jégvédő háló befolyásolja a gyümölcsök minőségét és beltartalmi értékeit. A legtöbb kutatás szerint - a háló színétől függő mértékben - növeli a terméshozamot, a gyümölcsméretet és a gyümölcsök tápelemtartalmát [8]8][11][12], de csökkenti a fedöszín mértékét, a húskeménységet, a beltartalmi értékeket (pl. cukor, sav, polifenol, C-vitamin) [3][4][6][11][14].

Kísérleteinkben három 'Gala' mutáns ('Anaglo', 'Brookfield', és 'Schniga') gyümölcsének beltartalmi (refrakció) és fizikai (húskeménység) paramétereit vizsgáltuk fekete jégvédő hálós, illetve jégvédő háló nélküli, intenzív termesztési körülmények között.

\section{Anyag és módszer}

A kísérletbe vont gyümölcsök Müller Jenő (Oleum 200 Kft.) fekete jégvédő hálóval fedett és anélkül termesztett gyümölcsültetvényeiböl (Kecskemét; 4650'24.2"N; 1940'08.0"E) származnak. A két ültetvény termesztéstechnológiája (müvelési rendszer, fito- és agrotechnika) azonos, kivéve a jéghálóval felszereltséget.

A vizsgálatokat a Neumann János Egyetem, Kertészeti és Vidékfejlesztési Karán végeztük el három 'Gala' mutánson ('Anaglo', 'Brookfield', és 'Schniga') (2. ábra). Ezen 'Gala' mutánsok érési ideje augusztus utolsó dekádja, így a szüretre augusztus végén (2019.08.26.) került sor, melyet vizsgálatok követtek. Annak érdekében, hogy pontos és valós adatokat mérhessünk a három vizsgált fajtának szüretelésére egyszerre került sor.

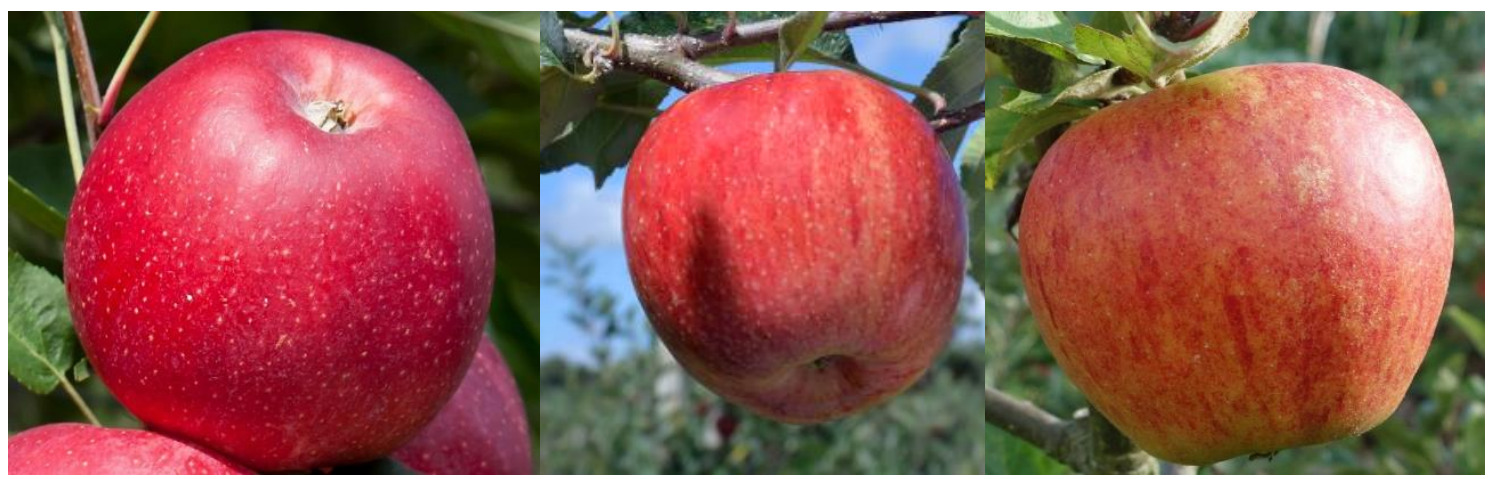

2. ábra. A kísérletben szereplö almafajták (balról jobbra: 'Anaglo'; 'Brookfield’ és 'Schniga)

A magyar élelmiszerkönyv fogalma a vízben oldható szárazanyag-tartalomra: „az élelmiszerből kipréselhető folyadék refraktométerrel $20{ }^{\circ} \mathrm{C}$-on mért törésmutatója, amelyet a tartósiparban cukorszázalékban (szacharóz) kifejezett értékkel (Ref\%) adnak meg" [7]. A fogalomnak megfelelően fajtánként, ill. kezelésenként (jéghálós vagy jégháló nélküli) 5-5 gyümölcs mindkét feléböl véletlen mintavételezéssel, és homogén gyümölcslé elkészítése után vízoldható szárazanyag-tartalom vizsgálatára került sor kézi refraktométerrel, melyet BRIX\%-ban, azaz $\mathrm{g} / 100 \mathrm{~g}$ értékben adtunk meg. A vizsgálat során kapott adatokat fajtánként, ill. kezelésenként átlagoltuk.

A fizikai tulajdonságok közül a gyümölcshús keménységének vizsgálatára került sor. Ez a tulajdonság azért fontos, mert meghatározza a szüreti időt, és nagyban befolyásolja az alma tárolhatóságát. A mintavételezésre úgy került sor, hogy fajtánként, ill. kezelésenként (jéghálós vagy jégháló nélküli) 5-5 gyümölcs napos, illetve árnyékos oldaláról 2-2 véletlenszerü ponton a gyümölcshéjat eltávolítottuk, majd a húskeménységet kézi penetrométerrel mértük. Az így kapott adatokat fajtától és kezeléstöl függően átlagoltuk és $\mathrm{g} / \mathrm{cm}^{2}$-ben adtuk meg. 


\section{Eredmények és megvitatás}

\subsection{Húskeménység alakulása fekete jégvédő háló alatt és anélkül termett gyümölcsöknél}

A fajták átlagos húskeménysége $5,05-6,79 \mathrm{~kg} / \mathrm{cm}^{2}$ között alakult (3. ábra). Mivel a vizsgálatokban ugyanannak a fajtának a mutánsai szerepeltek, a vártnak megfelelően nem volt jelentős különbség a fajták között azonos kezelés (fekete jéghálós vagy anélkül) mellett. Mindhárom fajta esetében azt tapasztaltuk, hogy a kontroll gyümölcsök húskeménysége magasabb volt, mint a fekete jégháló alatt termett gyümölcsöké. Jégvédő háló nélküli termesztéstechnológia esetén 1,2-1,4 $\mathrm{kg} / \mathrm{cm}^{2}$-rel nagyobb húskeménységeket mértünk. Eredményeinkhez hasonlóan - a háló színétől függő mértékben -, de minden esetben a kontroll gyümölcsöknél alacsonyabb húskeménységet mértek más kutatók [3][6][11][14] is jégháló alatt termett gyümölcsöknél. Ribárszki (2017) ennek az ellenkezőjét tapasztalta [8]. Treder (2016) kutatásában a fehér színű háló nem eredményezett szignifikáns különbséget [14].

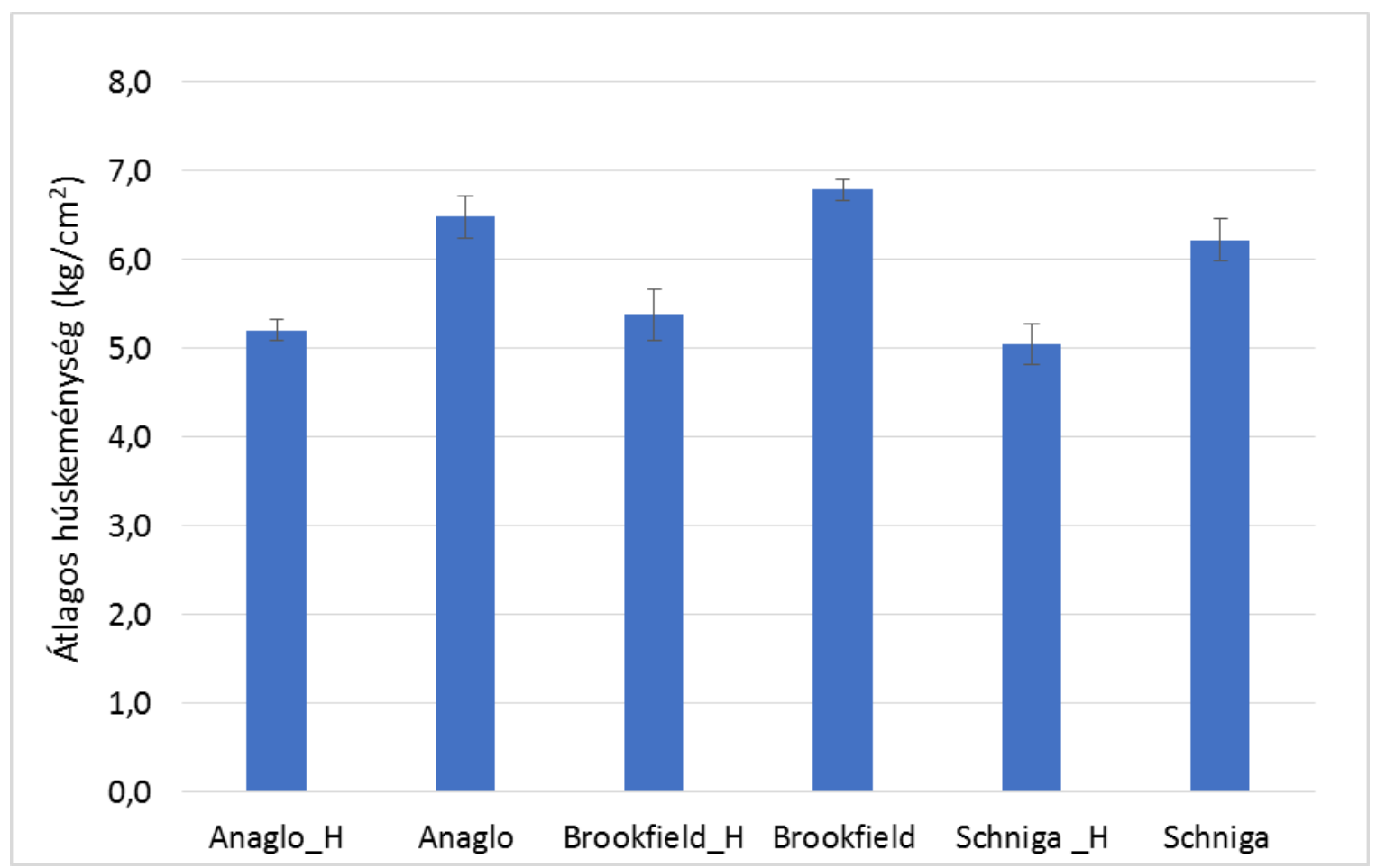

3. ábra. Almafajták átlagos húskeménysége $\left(\mathrm{kg} / \mathrm{cm}^{2}\right)$ fekete jégvédő hálós $(H)$ és jégvédőháló nélküli termesztési körülmények között (Kecskemét, 2019)

\subsection{Vízoldható szárazanyag-tartalom alakulása fekete jégvédő háló alatt és anélkül termett gyümölcsöknél}

Az átlagos vízoldható szárazanyag-tartalom (4. ábra) mennyisége fekete jégvédő hálós termesztési körülmények között szintén alacsonyabb a kontroll - jégvédőháló nélküli - termesztési körülményekhez képest. A fajták átlagos vízoldható szárazanyag-tartalma 11,05-13,30 Brix \% (azaz g/100g) között volt. A kontroll gyümölcsök vízoldható szárazanyag-tartalma 1,6-2,1 Brix \%kal volt magasabb. Az azonos körülmények között termesztett fajták között nem volt jelentős különbség. A kutatók többsége jégvédő háló alatt termett gyümölcsök esetében alacsonyabb vízoldható szárazanyag-tartalmat mért [3][6][11][14]. 


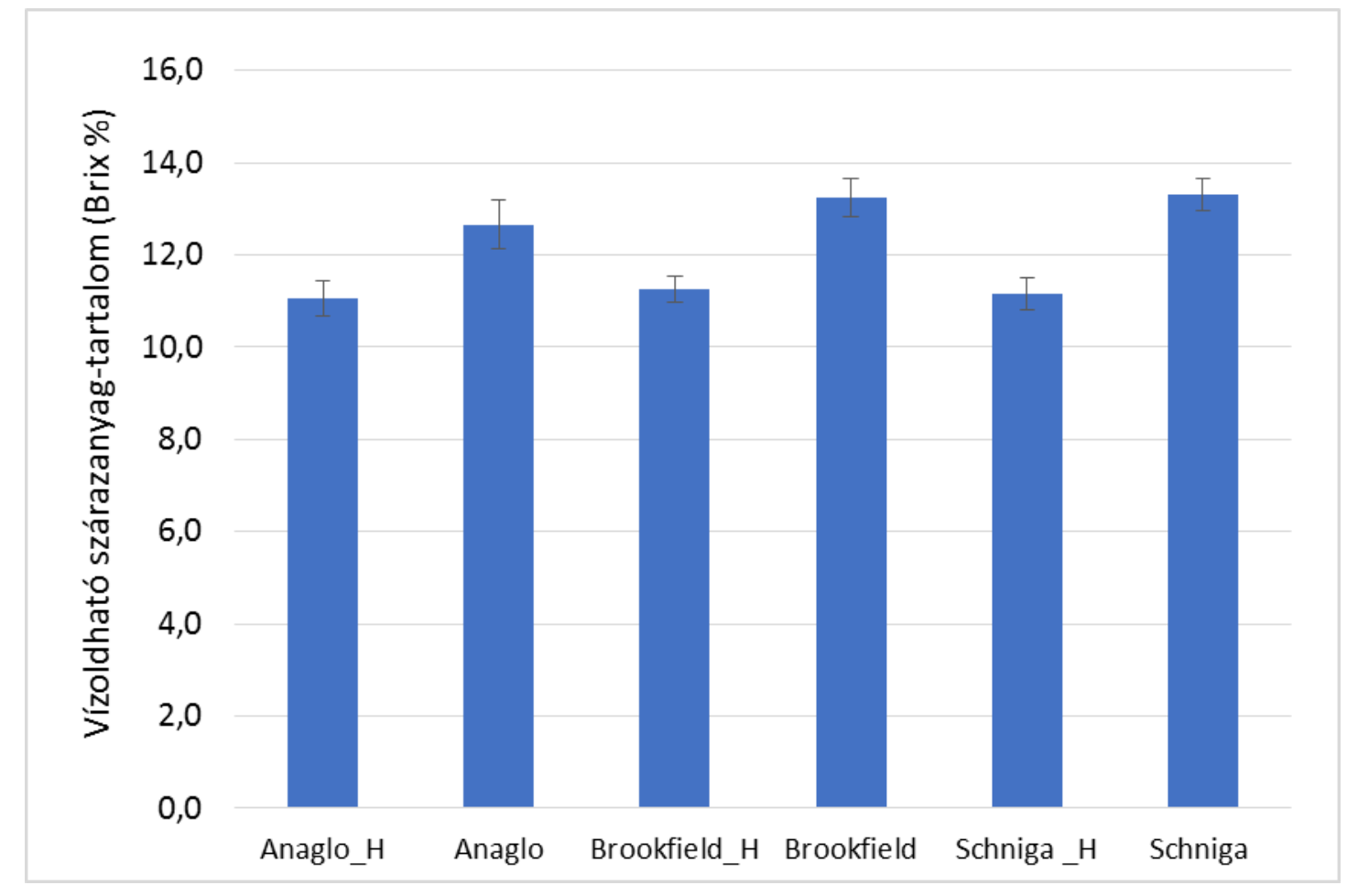

4. ábra. Almafajták vízoldható szárazanyag-tartalma (Brix\%) fekete jégvédő hálós $(H)$ és jégvédőháló nélküli termesztési körülmények között (Kecskemét, 2019)

\section{Következtetések, javaslatok}

A mérési adatok alapján arra lehet következtetni, hogy a jégvédő hálós termesztéstechnológia esetén lazább a vizsgált fajták húsállománya. Ennek föleg a pultállóság és a tárolhatóság terén van jelentősége. A termesztőknek figyelni kell arra is, hogy a fajtára általában jellemző húskeménységnél kissé alacsonyabb értékek nem feltétlen az érettebb állapotot jelzik, hanem a termesztési körülményeknek (jelen esetben jégháló) köszönhetöek.

A refrakció mérési eredményeink alapján az a következtetés vonható le, miszerint a jégvédő háló nélküli termesztés esetén a vizsgált fajták vízoldható szárazanyag-tartalma kis mértékben (kb. 10\%-kal) magasabb. Ez a gyümölcstulajdonság befolyásolhatja az ízvilágot és a zamatot.

A gyümölcsök beltartalmi és egészségvédő értékének (cukor- és savösszetevők, polifenoltartalom), valamint az ásványielem-tartalmának vizsgálata folyamatban van. Tervezzük a vizsgálatok megismétlését 2020-ban, és szeretnénk kiegészíteni vizsgálatainkat hőmérséklet és fényintenzitás mérésekkel is.

\section{Köszönetnyilvánítás}

Köszönjük Müller Jenönek a kísérlethez biztosított almákat.

Köszönettel tartozunk a kutatás támogatásáért, amely az EFOP-3.6.2-16-2017-00012 „Funkcionális, egészséges és biztonságos élelmiszer termékpálya modell kidolgozása a szántóföldtől az asztalig elv alapján, tematikus kutatási hálózatban” pályázat keretében valósult meg. A projekt a Magyar Állam és az Európai Unió támogatásával, az Európai Szociális Alap társfinanszírozásával, a Széchenyi 2020 program keretében valósul meg. 


\section{Irodalomjegyzék}

[1] Blanke, M.M. 2007. Farbige Hagelnetze: Ihre Netzstruktur sowie Licht- und UV-Durchlässigkeit bestimmen die Ausfärbung der Apfelfrüchte. Erwerbs-Obstbau. 49:127-139. DOI: https://doi.org/10.1007/s10341-007-0048-6

[2] Blanke, M.M. 2008. Alternatives to reflective mulch cloth (Extenday ${ }^{\mathrm{TM}}$ ) for apple under hail net? Scientia Horticulturae. 116(2): 223-226. DOI: https://doi.org/10.1016/j.scienta.2007.12.004

[3] Bosco, L.C., Bergamaschi, H., Cardoso, L.S., de Paula, V.A., Arduino, G., Marodini, B., Nachtigall, G.R. 2015. Apple production and quality when cultivated under anti-hail cover in Southern Brazil. International Journal of Biometerology. 59: 773-782.

[4] Brglez Sever, M., Tojnko, S., Unuk, T. 2015. Impact of various types of anti-hail nets on light exposure in orchards and quality parameters of apples- a rewiev. Agricultura 12(1-2): 25-31.

[5] Gonda I., Apáti F. 2013. Versenyképes almatermesztés. Szaktudás Kiadó Ház Zrt., Budapest

[6] Iglesias I., Alegre S. 2006. The effect of anti-hail nets on fruit protection, radiation, temperature, quality and profitability of 'Mondial Gala' apples. Journal of Applied. Horticulture. 8(2): 91-100.

[7] Magyar Élelmiszerkönyv 2-33 számú irányelv, Tartósított élelmiszerek 3. módosítótt kiadás (2010) p.5. https://elelmiszerlanc.kormany.hu/download/5/35/b1000/2-33.pdf

[8] Ribárszki Á. 2017. Jégháló hatásainak vizsgálata az alma humán egészségvédő fitonutriensek értékeire. Diplomamunka. PAE-KVK, Kecskemét

[9] Ribárszki Á. 2018. Jégeső ellen védőháló alkalmazása intenzív gyümölcsültetvényekben . Agrofórum. 27(10): 135137. https://agroforum.hu/szakcikkek/gyumolcs/jegeso-ellen-vedohalo-alkalmazasa-intenzivgyumolcsultetvenyekben/

[10] Solomakhin, A.A., Trunov, Y.V. , Blanke, M. 2011. The light conditions under protected coloured hailnets affect leaf anatomy, growth as well as fruit blush development in apple. Acta Hortic. 907:221-224. DOI: 10.17660/ActaHortic.2011.907.33

[11] Solomonkhin, A., Blanke M.M. 2010. Can coloured hailnets improve taste (sugar, sugar: acid ratio), consumer appeal (colouration) and national value (anthocyanin, Vitamin C) of apple fruits? - LWT Food Science and Technology 43 (2010) 1277-1284. DOI:10.1016/j.Iwt.2010.02.020

[12] Stampar, F., Veberic, R., Zadravec, P., Hudina, M., Usenik, V., Solar, A., Osterc, G. 2002. Yield and fruit quality of apples cv. 'Jonagold' under hail protection nets. Gartenbauwissenschaft. 67(5): 205-210.

[13] Tasin M., Demaria D., Ryne C., Cesano A., Galliano A., Anfora G., loriatti C., Alma A. (2008): Effect of anti-hail nets on Cydia pomonella behavior in apple orchards. Entomologia Experimentalis et Applicata. 129(1): 32-36. DOI: 10.1111/j. 1570-7458.2008.00748.x

[14] Treder, W., Mika, A., Buler, Z., Klamkowski, K. 2016. Effects of hail nets on orchard light microclimate, apple tree growth, fruiting and fruit quality. Acta Sci. Pol. Hortorum Cultus, 15(3), 17-27. 